\title{
THE GOMPLEK RELATIONSHIP BETWEEN INTERNATIONAL TOURISM DEMAND AND ECONOMIC GROWTH: AN ANALYSIS ON GENTRAL AND EASTERN EUROPEAN ECONOMIES
}

\author{
Alina Bădulescu ${ }^{1 *}$, Daniel Bădulescu ${ }^{2}$ and Ramona Simuț ${ }^{3}$ \\ ${ }^{1)}$ 2) ${ }^{3)}$ University of Oradea, Oradea, Romania
}

Please cite this article as:

Bădulescu, A., Bădulescu, D. and Simuț, R., 2018. The

Complex Relationship between International Tourism

Demand and Economic Growth: An Analysis on Central and Eastern European Economies. Amfiteatru Economic, 20(Special No. 12), pp. 935-950.

DOI: 10.24818/EA/2018/S12/935

\section{Article History}

Received: 20 August 2018

Revised: 17 September 2018

Accepted: 10 October 2018

\begin{abstract}
Tourism is widely considered as driver for economic growth, and the "tourism-led-growth hypothesis" is often investigated in the literature. However, there is very limited literature examining how economic growth impacts tourism, an impact which is usually tacitly accepted, without being analytically investigated.

In this paper we examine the impact of the economic growth on the number of international tourism arrivals and also on the international tourism receipts during 1995-2015, in Central and Eastern European economies, by using the Autoregressive Distributed Lag (ARDL) model. The bounds F-statistics for cointegration test provide evidence of a long-term relationship between the international tourism number of arrivals and GDP per capita only for Bulgaria, Croatia, Czech Republic, Estonia, Lithuania, Slovenia, Romania and Slovakia. Between international tourism receipts and GDP per capita we find a long-term relationship only for Bulgaria, Croatia, Slovakia, Latvia, Estonia, Poland, Romania and Czech Republic. We also explore causal relationship between the variables by using an error-correctionbased Granger causality model (short-run and long-run), finding different unidirectional / bidirectional short/long-term relationships between international tourism demand (measured by two proxies: international tourist arrivals and international tourism receipts) and economic growth (measured by GDP per capita), in different countries.

The paper contributes to better understanding the nature and the direction of the relationship between tourism sector and economic growth, aiming not only to enrich the literature in the field, but also to design specific economic growth policies with an impact on tourism sector.
\end{abstract}

Keywords: international tourism demand, economic growth, Granger causality, ARDL model, Central and Eastern European countries.

JEL Classification: Z32, L83, C32, O11, O52.

*Corresponding author, Alina Bădulescu - abadulescu@ uoradea.ro 


\section{Introduction}

The tourism industry is one of the most important and fast-growing industries around the world, providing $10 \%$ of the global GDP, $7 \%$ of global trade, $30 \%$ of world services exports, and one in 10 jobs (World Tourism Organization (UNWTO), 2016).

Europe's figures are even more impressive. The entire European continent holds about $51 \%$ of international tourist arrivals, meanwhile EU's countries hold over $40 \%$ from total, and Europe's international receipts from tourism (in 2015) reached more than 406 billion Euros (36\% of the total world). EU economies account for revenues of 336.5 billion Euros, i.e. almost $30 \%$ of the world total revenues in international tourism (World Tourism Organization (UNWTO), 2016). Although the role of tourism in fostering growth is widely recognized (the so-called tourism-led-growth hypothesis), in this article we mostly examine the other direction of the relation: how economic growth affects tourism, i.e. economic driven tourism growth hypothesis, and we focus on performing the analysis not only at the level of one single economy, but on a homogeneous group of economies. More precisely, we will investigate how economic growth impacted the number of international tourism arrivals and the international tourism receipts during 1995-2015, in Central and Eastern European economies.

The paper is organized as follows: in the first part we review the literature regarding the relation between tourism and economic growth, revealing the complex and bi-directional relation between them. In the second part we present the research methodology. In the third part we present the empirical results and the discussion of them, and in the final part we conclude.

\section{Literature review}

For many economies, the tourism industry bears a particular significance, not only through the income generated, but also as a supplier of jobs, currency flows, entrepreneurial dynamism, and contributor to regional development (Tigu, 2012). Thus, in the last decades, the connection between tourism and economic growth is noticeable and has generated a significant number of studies and articles.

The literature regarding the relation between tourism and economic growth is relatively recent, due to most classical theories (either neoclassical or endogenous growth theories) lacking references to tourism and its role in economic growth. Either adapting neoclassical theories, supporting the free market, the liberalization of trade and foreign investment (assimilating international tourism to a form of export), or insisting on the active role of the state in promoting direct and indirect investments or the role of human capital in stimulating efficiency and growth, researchers have elaborated theories able to describe the contribution of tourism to economic growth. Thus, Lanza and Pigliaru (2000) state that countries where tourism has a considerable contribution to GDP register above average growth rates. Consequently, investment in sectors benefiting from abundant natural resources (i.e. tourism) will stimulate a greater economic growth rate. Balaguer and Cantavella-Jorda (2002) describe the role of tourism through spillovers and externalities.

However, there is no consensus, theoretical or practical, about the relation between tourism and economic activity, especially whether tourism supports economic growth or, conversely, economic growth leads to the development of tourism. Additionally, changes in 
the economic conditions and the evolution of tourism may influence the nature and amplitude of the two series (Antonakakis et al., 2015).

It is likely that the recent global economic crisis started in 2007-2008 and its effects on economic development and the evolution of tourism rekindled the interest of researchers, practitioners and policy makers in the relation between tourism and economic growth, including defining the framework for tourism development at regional and national level.

Usually, tourism expansion is analysed in terms of number of tourist arrivals or international tourism receipts, while economic growth is most commonly associated with a constantly positive evolution of the GDP. Nevertheless, there are still controversies regarding even the indicators used or their practical significance. Several authors (Ridderstaat et al., 2016) consider that the above-mentioned indicators ignore the entities directly involved and affected by the development of tourism, such as local communities in destination countries, who often enjoy minimal benefits from tourism or general economic growth. They support the inclusion of more adequate indicators related to the field of human development (Ridderstaat et al., 2016) and sustainable development (Popescu et al., 2014; Haţegan and Ivan-Ungureanu, 2014; Badulescu et al., 2015).

Reviewing the literature on the topic, it appears that studies attempting to determine the relation between tourism and economic growth have established four main hypotheses, grouped as follows:

- a unidirectional causality, represented by:

- tourism-led economic growth hypothesis - TLEG or tourism-led growth hypothesis TLGH, and, conversely,

- economic driven tourism growth hypothesis - EDTG or growth-led tourism hypothesis - GLTH;

- a bidirectional relationship between tourism and the economy (bidirectional causality hypothesis - BC) and, finally

- no causality hypothesis - NC.

We will briefly present them here.

\subsection{The unidirectional causality hypothesis}

According to the tourism-led economic growth hypothesis - TLEG (the best represented hypothesis, both in theory and practice), tourism stimulates gains derived from foreign exchange, encourages investments, enhances the competitiveness of small enterprises through increased competition and requirements of external visitors (Balaguer and Cantavella-Jorda, 2002), generating positive externalities for other sectors (Durbarry, 2004; Bac and Aksoz, 2015), alleviating unemployment in destination areas (Andriotis, 2002; Brida and Pulina, 2010), generating public revenues (Brida et al., 2014), leads to positive economies of scale (Andriotis, 2002).

Tourism is considered a valuable export, while the opening of internal tourism to the international flow is considered a superior strategy when compared to policies supporting import substitution. By using cointegration techniques and the Granger causality test to study the impact of tourism on growth, Balaguer and Cantavella-Jorda (2002) for Spain, Arslanturk and Atan (2012) for Turkey, found that an expanding tourism sector can stimulate economic growth unidirectionally: from tourism to GDP or "the tourism expenditure unidirectionally affects economic growth" (Brida et al., 2014, p.5). By using a multivariate model derived from the Solow growth theory on a number of series of annual 
data (1975-2011) from Malaysia, Tang and Tan (2015) report that economic growth, tourism and other determinants are cointegrated, and tourism has a positive impact on Malaysia's economic growth both in the short-run and in the long-run, i.e. "tourism Granger-causes economic growth" (Tang and Tan, 2015, p. 158). The reliability of results determines the authors to decisively state that any political initiative promoting tourism could contribute to economic growth, structural diversification and resilience of Malaysian economy, but with potential for a more general applicability to other economies, especially to those seeking for new sources of growth and development (Tang and Tan, 2015, p. 162). This confirms the deductions of the seminal paper of Balaguer and Cantavella-Jorda (2002), who stated that "tourism-led growth is not specific of developing countries which base their foreign exchange earnings on the existence of a comparative advantage in certain sectors of the economy" (Balaguer and Cantavella-Jorda, 2002), but to developed countries as well.

There is, however, no consensus, and many authors are reticent in stating that tourism influences economic development. Arslanturk et al. (2011), applying several techniques such as Granger causality tests and Vector Error Correction Model (VECM), did not find any convincing argument supporting TLEG in Turkey. Aslan (2013), investigating the relation between tourism and economic growth on a series of Mediterranean countries, reported a unidirectional (TLEG) correlation for Spain, Italy, Tunisia, Cyprus, Croatia and Greece. Chou (2013) found that in 10 transition countries from the EU, the causality directions between tourism and economic growth is different. Namely, in Cyprus, Latvia and Slovakia a one-way TLEG relationship was identified, while a one-way EDTG relationship was reported in Czech Republic and Poland. When testing the TLEG hypothesis on countries affected by political instability and (uncontrolled) events (i.e. terrorism) such as Lebanon, Charbel et al. (2015) estimate a vector auto-regressive model with exogenous variables, applying a series of unit root tests with and without structural breaks and the Granger causality test. Their results "confirm the validity of a short-run relationship going from tourism to economic growth, despite the recurrent terrorist incidents", but no "long-run relationship between tourism development and economic growth" (Charbel et al., 2015, p. 53).

On the other hand, the second unidirectional hypothesis (economic driven tourism growth hypothesis - EDTG) states that tourism is affected by economic fluctuations. Analysing the relation between tourism and economic growth in Korea by using a bivariate autoregressive model (VAR) and the Granger two-stage approach (Granger, 1981; Engle şi Granger 1987), Oh (2005) reported no cointegration between tourism and economic growth: "the results of cointegration test indicate that there is no long-run equilibrium relationship between these two series" (Oh, 2005, p. 39), which supports EDTG, and thus came to the conclusion of a unidirectional causality running from economic growth to tourism. In an empirical study examining the tourism-led growth hypothesis for Croatia, using the Toda-Yamamoto longrun causality tests for quarterly set of data between 2000 and 2008, Payne and Mervar (2010) assert the existence of a "positive unidirectional causality from real GDP to international tourism revenues, as well as positive unidirectional causality from real GDP to the real effective exchange rate" (Payne and Mervar, 2010, p.1089): in different words, a support for the economic-driven tourism growth hypothesis. Rivera (2016), using a cointegration methodology with an error-correction model to assess the dynamic relationship between human development, economic growth and tourism in Ecuador, found that tourism only has a long-term effect on economic growth and the causal relationship is reciprocal (Rivera, 2016) on short-run Granger causality. His study found a unidirectional causality 
supporting the economic driven tourism growth, meaning that tourism growth is a product of economic growth but not vice-versa. Sustained economic growth, intelligent use of resources, the implementation of well-designed economic policies, the existence of a positive economic climate and the development of infrastructure encourage the proliferation and development of tourism initiatives.

\subsection{The bidirectional causality hypothesis (BC)}

Kim et al. (2006), Cortés-Jimenez and Pulina (2006), Lee and Chang (2008), Apergis and Payne (2012) assert a bidirectional causality hypothesis $(B C)$ between tourism incomes and economic growth, explained from the perspective of public policies. These policies should take into account both the general development of the economy and the development of specific sectors (especially when relying on abundant and accessible natural resources), such as tourism. A more nuanced approach is provided by Lee and Chang (2008) who, analysing a large number of countries with various economic structures and development levels, come to the conclusion that most OECD countries are characterized by "unidirectional causality relationships from tourism growth to economic development (...), but bidirectional causality relationships are found between the two variables in non-OECD countries" (Lee and Chang, 2008, p.191). A similar approach, but more critical with respect to the practical utility of the deductions of empirical research on the tourism-development relationship, is stated by Cardenas-Garcia et al. (2015) who, after analysing 144 countries, consider that "we must be critical of such approaches, which accept the universal validity of tourism as a tool for development and poverty reduction" (Cárdenas-García et al., 2015, p. 217). Finally, Aslan (2013) reports a bidirectional relation only for Portugal, while Chou (2013) identifyes a bidirectional relation for Estonia and Hungary.

\subsection{The no causality hypothesis (NC)}

Finally, there are also (relatively few) studies that do not comply with any of the above hypotheses (no causality hypothesis - NC) and suggest that the relationship between tourism and economic growth is insignificant or unconvincing (Katircioglu, 2009) or not stable (Jackman, 2012). Tang and Jang (2009), by using Johansen cointegration test (Johansen, 1988; Johansen and Juselius, 1990) and Granger causality tests, found there is no long-term relationship between tourism industry and the economic growth for the case of US. For Turkey, Ozturk and Acaravci (2009), using the Autoregressive Distributed Lag (ARDL) bounds testing approach, find that between tourism and economic growth does not exist a causality relationship. Aslan (2013) identify no obvious relation for Malta and Egypt, while Chou (2013) reports no causal relationship for Bulgaria, Romania and Slovenia.

One of the vulnerabilities of this simplistic categorization of the tourism-economic growth relationship (regardless of its meaning, or even the contestation of its existence) is its static character, its apparent stability over time. Thus, Arslanturk et al. (2011) and Antonakakis et al. (2015) assert a dynamic perspective which may admit that the meaning of these relationships may change over time. For example, in a study performed on $10 \mathrm{EU}$ member-countries for the period 1995-2012, Antonakakis et al. (2015) examines the time-varying relationship between tourism growth and economic growth. Their findings reveal that the tourism-economic growth relationship is not stable over time in terms of magnitude and, moreover, "not only the magnitude, but also the direction of this economic growth and tourism growth relationship changes over time" (p. 153), and the same country in different periods of time "can experience tourism-led economic growth or economic-driven tourism growth" (Antonakakis et al., p.153).

Vol. $20 \cdot$ Special No. $12 \cdot$ November 2018 
At the level of European countries surveyed, the authors noticed essential events influencing the trend (i.e. the Great Recession started in 2007, and the Eurozone debt crisis of 2010) as well as significant differences between the surveyed countries, i.e. a strong impact on tourism economic growth relations in countries such as Cyprus, Greece, Portugal and Spain, and moderate impact in countries like Germany, Netherlands or even Italy.

\section{Research methodology}

In investigating the presence of the relationship between the variables GDP per capita (constant 2010 US\$) (GDP) and international tourism, measured by the number of arrivals (ARIV), and also the presence of a relationship between GDP per capita (constant 2010 US\$) (GDP) and international tourism measured by the international tourism receipts (in current US\$) (REC), this study is using the ARDL approach and causal analysis. We used data provided by The World Bank database / World Development Indicators (The World Bank, 2017) for Central and Eastern European economies during 1995-2015. To ease the interpretation of the coefficients of the estimated models, the data is transformed through the use of the natural logarithm for each variable. We used the Eviews 9 software for econometric modeling.

Starting from these variables (GDP per capita, international tourist arrivals and international tourism receipts) we formulate the following hypotheses:

- H1: there is a long-run relationship between GDP per capita and international tourism demand;

- H2: there is a bidirectional relationship between GDP per capita and international tourism demand;

- H3: an increase in GDP per capita results in an increase in the international tourism demand (economic driven tourism growth hypothesis - EDTG).

The correlation we are following is non-linear (Brătianu and Vasilache, 2010, p. 395). The cointegration method used in our research is the so-called autoregressive distributed lag (ARDL) model, method that was introduced by Pesaran and Shin (1999) and further extended by Pesaran, Shin, and Smith (2001). This method presents certain econometric advantages compared to other cointegration procedures, namely: it is adequate for small size samples; some of the regressors are endogenous; the long-term and short-term parameters of the model are estimated simultaneously; is no need for all the variables to have the same order of integration and it allows that the variables may have different optimal lags (Pesaran et al., 2001). The ARDL model involves three main steps. The first step is to investigate the stationarity of all the variables by using the Augmented Dickey Fuller (ADF) test $(1979,1981)$. The second step is to test for cointegration for the studied variables for all selected countries and the third step is to test the causality.

The bounds test examines whether a long-run relationship exists between the variables:

$$
\begin{aligned}
& \Delta \mathrm{ARIV}_{\mathrm{t}}=\alpha_{1}+\sum_{\mathrm{k}=1}^{\mathrm{n}} \beta_{1 \mathrm{k}} \Delta \mathrm{ARIV}_{\mathrm{t}-\mathrm{k}}+\sum_{\mathrm{k}=0}^{\mathrm{n}} \beta_{2 \mathrm{k}} \Delta \mathrm{GDP}_{\mathrm{t}-\mathrm{k}}+\delta_{1} \mathrm{ARIV}_{\mathrm{t}-1}+\delta_{2} \mathrm{GDP}_{\mathrm{t}-1}+\varepsilon_{1 \mathrm{t}} \\
& \Delta \mathrm{REC}_{\mathrm{t}}=\alpha_{2}+\sum_{\mathrm{k}=1}^{\mathrm{n}} \theta_{1 \mathrm{k}} \Delta \mathrm{REC}_{\mathrm{t}-\mathrm{k}}+\sum_{\mathrm{k}=0}^{\mathrm{n}} \theta_{2 \mathrm{k}} \Delta \mathrm{GDP}_{\mathrm{t}-\mathrm{k}}+\delta_{3} \mathrm{REC}_{\mathrm{t}-1}+\delta_{4} \mathrm{GDP}_{\mathrm{t}-1}+\varepsilon_{2 \mathrm{t}}
\end{aligned}
$$


In order to test the long-run relationship among the variables: ARIV - number of international tourist arrivals, GDP - Gross Domestic Product, REC - international tourism receipts, a first step in the ARDL cointegration method is to estimate the above equations by OLS method. The second step is to estimate the following long-term and short-term models.

$$
\begin{aligned}
& \Delta \text { ARIV }_{\mathrm{t}}=\mu_{1}+\sum_{\mathrm{k}=1}^{\mathrm{n}} \gamma_{11 \mathrm{k}} \Delta \mathrm{ARIV}_{\mathrm{t}-\mathrm{k}}+\sum_{\mathrm{k}=0}^{\mathrm{n}} \gamma_{12 \mathrm{k}} \Delta \mathrm{GDP}_{\mathrm{t}-\mathrm{k}}+\lambda_{1} \mathrm{ECT}_{\mathrm{t}-1}+\varepsilon_{3 \mathrm{t}} \\
& \Delta \mathrm{REC}_{\mathrm{t}}=\mu_{3}+\sum_{\mathrm{k}=1}^{\mathrm{n}} \gamma_{31 \mathrm{k}} \Delta \mathrm{REC}_{\mathrm{t}-\mathrm{k}}+\sum_{\mathrm{k}=0}^{\mathrm{n}} \gamma_{32 \mathrm{k}} \Delta \mathrm{GDP}_{\mathrm{t}-\mathrm{k}}+\lambda_{2} \mathrm{ECT}_{\mathrm{t}-1}+\varepsilon_{5 \mathrm{t}},
\end{aligned}
$$

where $\lambda_{1}$ and $\lambda_{2}$ represent the speed of adjustment parameter and ECT is the error correction term.

Thus, to determine the causal relationship between the number of international tourist arrivals (ARIV) and the Gross Domestic Product (GDP) we have:

$$
\left[\begin{array}{l}
\Delta \mathrm{ARIV}_{\mathrm{t}} \\
\Delta \mathrm{GDP}_{\mathrm{t}}
\end{array}\right]=\left[\begin{array}{l}
\mu_{1} \\
\mu_{2}
\end{array}\right]+\left[\begin{array}{l}
\gamma_{11,1} \\
\gamma_{21,1}
\end{array}\right]\left[\begin{array}{l}
\Delta \mathrm{ARIV}_{\mathrm{t}-1} \\
\Delta \mathrm{GDP}_{\mathrm{t}-1}
\end{array}\right]+\ldots+\left[\begin{array}{l}
\gamma_{11, \mathrm{k}} \\
\gamma_{21, \mathrm{k}}
\end{array}\right]\left[\begin{array}{l}
\Delta \mathrm{GDP}_{\mathrm{t}-\mathrm{k}} \\
\Delta \mathrm{ARIV}_{\mathrm{t}-\mathrm{k}}
\end{array}\right]+\left[\begin{array}{l}
\lambda_{1} \\
\lambda_{3}
\end{array}\right] \mathrm{ECT}_{\mathrm{t}-1}+\left[\begin{array}{l}
\varepsilon_{3 \mathrm{t}} \\
\varepsilon_{4 \mathrm{t}}
\end{array}\right]
$$

while for determining the causal relationship between the international tourism receipts (REC) and the Gross Domestic Product (GDP) we have the following models:

$$
\left[\begin{array}{c}
\Delta \mathrm{REC}_{\mathrm{t}} \\
\Delta \mathrm{GDP}_{\mathrm{t}}
\end{array}\right]=\left[\begin{array}{l}
\mu_{3} \\
\mu_{4}
\end{array}\right]+\left[\begin{array}{l}
\gamma_{31,1} \\
\gamma_{41,1}
\end{array}\right]\left[\begin{array}{l}
\Delta \mathrm{REC}_{\mathrm{t}-1} \\
\Delta \mathrm{GDP}_{\mathrm{t}-1}
\end{array}\right]+\ldots+\left[\begin{array}{c}
\gamma_{31, \mathrm{k}} \\
\gamma_{41, \mathrm{k}}
\end{array}\right]\left[\begin{array}{l}
\Delta \mathrm{GDP}_{\mathrm{t}-\mathrm{k}} \\
\Delta \mathrm{REC}_{\mathrm{t}-\mathrm{k}}
\end{array}\right]+\left[\begin{array}{l}
\lambda_{2} \\
\lambda_{4}
\end{array}\right] \mathrm{ECT}_{\mathrm{t}-1}+\left[\begin{array}{c}
\varepsilon_{5 \mathrm{t}} \\
\varepsilon_{6 \mathrm{t}}
\end{array}\right]
$$

Starting from the above equations, we can examine the causal relationships in two ways: 1) short-run Granger causality is identified through the F-statistic test for the significance of the relevant $\gamma$ coefficients on the first differenced series; 2) the long-run Granger causality is identified through the t-test for the significance of the relevant $\lambda$ coefficients on the lagged ECT.

\section{Empirical results and discussion}

In order to determine the impact of the economic growth on the exports from international tourism in the Central and Eastern European countries, we used the ARDL model and the Granger causality test. The analysis starts by investigating the stationarity or unit root test of the variables number of international tourist arrivals (ARIV), international tourism receipts (REC) and GDP. For the purpose of the analysis, the variables were transformed to natural logarithms. In the present study we use the Augmented Dickey Fuller test (Dickey and Fuller, 1979).

In table no. 1 we present the ADF (Augmented Dickey-Fuller) test results which indicate that the null hypothesis is rejected at the 5\% level of significance after the first difference for most of the variables in all countries. This means that all these variables have a unit root and is stationary at the first difference and denoted as I(1). 
Table no 1: Unit root test results (ADF test)

\begin{tabular}{|c|c|c|c|c|}
\hline \multirow{2}{*}{ Country } & \multicolumn{4}{|c|}{ Variables } \\
\hline & \multicolumn{2}{|r|}{ LGDP } & LARIV & \multirow{3}{*}{$\begin{array}{c}\text { LREC } \\
-1.529712(0.49) \\
-4.08881(0.00)\end{array}$} \\
\hline \multirow{2}{*}{ Bulgaria } & ADF (level) & $-0.661429(0.83)$ & $0.016563(0.94)$ & \\
\hline & $\mathrm{ADF}\left(1^{\text {st }}\right.$ diff $)$ & $-2.933035(0.06)$ & $-4.803055(0.00)$ & \\
\hline \multirow{2}{*}{ Croatia } & ADF (level) & $-3.018238(0.05)$ & $-0.573165(0.85)$ & $-2.849139(0.06)$ \\
\hline & $\operatorname{ADF}\left(1^{\text {st }}\right.$ diff $)$ & & $-5.180844(0.00)$ & \\
\hline \multirow{2}{*}{$\begin{array}{c}\text { Czech } \\
\text { Republic }\end{array}$} & ADF (level) & $-0.890074(0.76)$ & $-2.194314(0.21)$ & $-1.336764(0.58)$ \\
\hline & $\operatorname{ADF}\left(1^{\text {st }}\right.$ diff $)$ & $-2.777355(0.08)$ & $-5.254203(0.00)$ & $-3.970481(0.00)$ \\
\hline \multirow{2}{*}{ Estonia } & ADF (level) & $-1.503961(0.50)$ & $-3.472714(0.02)$ & $-1.370198(0.57)$ \\
\hline & $\operatorname{ADF}\left(1^{\text {st }}\right.$ diff $)$ & $-3.568301(0.01)$ & & $-3.2824807(0.01)$ \\
\hline \multirow{2}{*}{ Hungary } & ADF (level) & $-1.572026(0.47)$ & $1.061638(0.99)$ & $-1.411547(0.55)$ \\
\hline & $\operatorname{ADF}\left(1^{\text {st }}\right.$ diff $)$ & $-2.775766(0.08)$ & $-3.678590(0.01)$ & $-5.181755(0.00)$ \\
\hline \multirow{2}{*}{ Latvia } & ADF (level) & $-1.315369(0.59)$ & $-0.538201(0.86)$ & $-2.895853(0.06)$ \\
\hline & $\operatorname{ADF}\left(1^{\text {st }}\right.$ diff $)$ & $-3.472761(0.02)$ & $-3.260560(0.03)$ & \\
\hline \multirow{2}{*}{ Lithuania } & ADF (level) & $-1.285113(0.61)$ & $-2.870316(0.06)$ & $-1.894527(0.32)$ \\
\hline & $\operatorname{ADF}\left(1^{\text {st }}\right.$ diff $)$ & $-3.312942(0.02)$ & & $-3.189390(0.03)$ \\
\hline \multirow{2}{*}{ Poland } & ADF (level) & $-1.861973(0.34)$ & $-2.669648(0.09)$ & $-1.010278(0.72)$ \\
\hline & $\operatorname{ADF}\left(1^{\text {st }}\right.$ diff $)$ & $-3.691554(0.01)$ & & $-3.232815(0.03)$ \\
\hline \multirow{2}{*}{ Romania } & ADF (level) & $-0.066191(0.94)$ & $0.192916(0.96)$ & $-0.542414(0.86)$ \\
\hline & $\operatorname{ADF}\left(1^{\text {st }}\right.$ diff $)$ & $-2.775732(0.08)$ & $-5.384943(0.00)$ & $-3.189666(0.03)$ \\
\hline \multirow{2}{*}{ Slovakia } & ADF (level) & $-1.070467(0.70)$ & $-1.293206(0.61)$ & $-0.538584(0.86)$ \\
\hline & $\operatorname{ADF}\left(1^{\text {st }}\right.$ diff $)$ & $-3.177511(0.03)$ & $-4.448736(0.00)$ & $-2.674133(0.09)$ \\
\hline \multirow{2}{*}{ Slovenia } & ADF (level) & $-2.532679(0.12)$ & $-0.512633(0.86)$ & $-1.579325(0.47)$ \\
\hline & $\operatorname{ADF}\left(1^{\text {st }}\right.$ diff $)$ & $-2.942086(0.05)$ & $-4.555974(0.00)$ & $-2.492670(0.13)$ \\
\hline
\end{tabular}

Notes: p-value are in ().

Source: Authors' estimates using Eviews 9

The GDP variable from Croatia, as well as the number of international tourist arrivals from Estonia, Lithuania and Poland also are found to be stationary at level and denoted as $\mathrm{I}(0)$. Regarding the variable international tourism receipts, we can conclude that in the case of Slovenia this variable is not stationary neither at level, nor at first order difference.

Since the order of integration of this variable is greater than one, the ARDL bounds testing approach of cointegration cannot be used. Because the unit root results have confirmed that almost all variables are integrated $\mathrm{I}(0)$ or $\mathrm{I}(1)$ or mixture of both, the ARDL-bounds test developed by Pesaran et al. (2001) will be used to test for cointegration, in order to examine the long-run relationship between the variables (table no. 2). The bounds of F-statistics for cointegration test yields evidence of a long-run relationship between the number of arrivals and the GDP per capita at 1\% significance level in Croatia, Estonia and Slovenia; at 5\% significance level in Bulgaria, Czech Republic, Lithuania, Romania and Slovakia; no longrun relationship has been found for Hungary, Latvia and Poland. 
Table no. 2: Estimated ARDL models and bounds F-test for cointegration

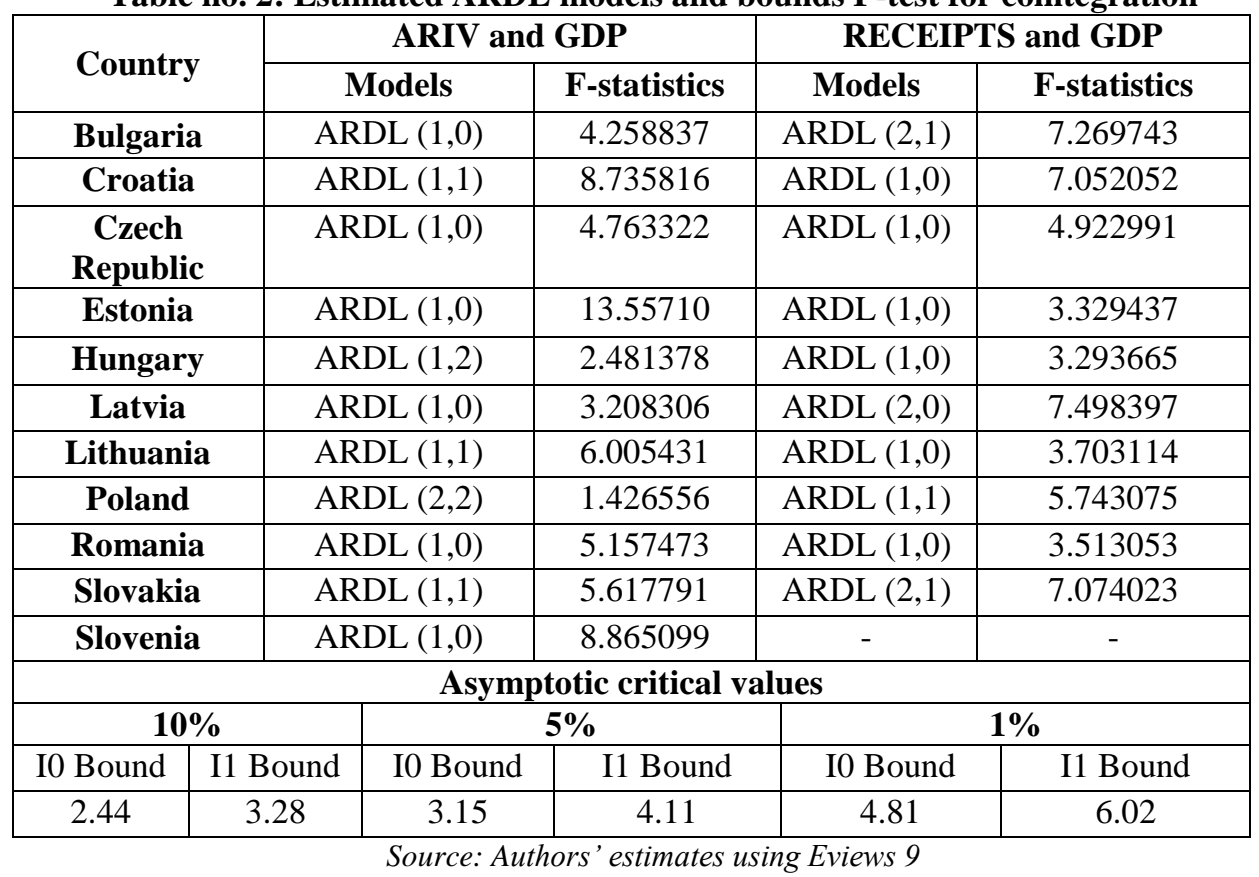

With regard to the relationship between the variables GDP and international tourism receipts, the bounds F-statistics for cointegration test reports a long-run relationship between the mentioned variables at $1 \%$ significance level for Bulgaria, Croatia, Latvia and Slovakia; at 5\% significance level for Czech Republic and Poland; at $10 \%$ significance level for Estonia and Romania; no long-run relationship has been found for Hungary and Lithuania. No significant ARDL model was found for Slovenia.

The long-run elasticity estimates of number of international tourist arrivals with respect to GDP per capita are expected to be positive. This means that an increase in GDP per capita results in an increase in the number of arrivals. Appendix no. 1 presents the estimated ARDL models for all Central and Eastern European countries. We found a positive coefficient at $1 \%$ significance level in Bulgaria, Croatia, Czech Republic, Estonia, Lithuania and Slovenia; at 5\% significance level in Romania, and at $10 \%$ significance level for Slovakia. All coefficients of estimated ECTs are negative and almost all are statistically significant at $1 \%$ confidence level, respectively at $5 \%$ confidence level. These values indicate that any deviation from the long-run equilibrium between variables is corrected for each period to return the long-run equilibrium level. In Appendix no. 2 we present the estimated ARDL models for the relationship between international tourism receipts and GDP per capita. For eight Central and Eastern European countries, we found a positive long-run elasticity estimate of international tourism receipts with respect to GDP per capita at $1 \%$ significance level. All the coefficients of estimated ECTs are negative and statistically significant at $1 \%$ confidence level. These values indicate that any deviation from the long-run equilibrium between variables is corrected for each period to return the long-run equilibrium level. 
We also explore in our study the causal relationship between the variables by using an error-correction based Granger causality model (table no. 3)

Table no. 3: Granger causality test results

\begin{tabular}{|c|c|}
\hline Hypothesis & The country where the hypothesis is accepted (probability) \\
\hline \multicolumn{2}{|r|}{ Short-run Granger causality (ARIV and GDP) } \\
\hline$\Delta \mathrm{GDP} \Rightarrow \Delta \mathrm{ARIV}$ & $\begin{array}{l}\text { Bulgaria (0.0081); Croatia }(0.0032) ; \text { Romania } \\
\text { Slovakia }(0.0867) ; \text { Slovenia }(0.0988)\end{array}$ \\
\hline$\Delta \mathrm{ARIV} \Rightarrow \Delta \mathrm{GDP}$ & $\begin{array}{l}\text { Bulgaria (0.082); Croatia (0.0011); Estonia (0.0340); Romania } \\
(0.0105) \text {; Slovenia }(0.0768)\end{array}$ \\
\hline \multicolumn{2}{|r|}{ Long-run Granger causality (ARIV and GDP) } \\
\hline $\mathrm{ECT} \Rightarrow \Delta \mathrm{ARIV}$ & Estonia $(0.0031) ;$ Slovenia $(0.0160)$ \\
\hline $\mathrm{ECT} \Rightarrow \Delta \mathrm{GDP}$ & $\begin{array}{l}\text { Czech Republic (0.0365); Lithuania (0.0025); Romania } \\
(0.0118) \text {; Slovakia }(0.0002)\end{array}$ \\
\hline \multicolumn{2}{|r|}{ Short-run Granger causality (REC and GDP) } \\
\hline$\Delta \mathrm{GDP} \Rightarrow \Delta \mathrm{REC}$ & $\begin{array}{l}\text { Bulgaria (0.10); Croatia (0.00); Czech Republic }(0.0124) \text {; } \\
\text { Estonia }(0.0339) \text {; Latvia }(0.0191) \text {; Poland }(0.0237) \text {; Romania } \\
(0.0036) \text {; Slovakia }(0.0093)\end{array}$ \\
\hline$\Delta \mathrm{REC} \Rightarrow \Delta \mathrm{GDP}$ & $\begin{array}{l}\text { Croatia (0.00); Czech Republic }(0.0007) \text {; Estonia }(0.0397) ; \\
\text { Poland }(0.0223) ; \text { Romania }(0.0043) ; \text { Slovakia }(0.0169)\end{array}$ \\
\hline \multicolumn{2}{|r|}{ Long-run Granger causality (REC and GDP) } \\
\hline $\mathrm{ECT} \Rightarrow \Delta \mathrm{REC}$ & Latvia $(0.0163) ;$ Poland $(0.0588)$ \\
\hline $\mathrm{ECT} \Rightarrow \Delta \mathrm{GDP}$ & $\begin{array}{l}\text { Bulgaria (0.01); Croatia (0.03); Czech Republic (0.00); Poland } \\
(0.00) \text {; Romania (0.0041); Slovakia }(0.0005)\end{array}$ \\
\hline
\end{tabular}

Notes: The null hypothesis is that there is no causal relationship between variables. The p-value are in ( ).

Source: Authors' estimates using Eviews 9

The results of short-run and long-run Granger causality between ARIV and GDP can be summarized as follows: (1) there is a short-run bidirectional relationship in Bulgaria, Croatia, Romania and Slovenia; (2) there is short-run unidirectional relationship in Estonia (from ARIV to GDP) and Slovakia (from GDP to ARIV); (3) there is no evidence of a long-run bidirectional relationship between ARIV and GDP, but there is evidence of a longrun unidirectional relationship in Bulgaria, Czech Republic, Estonia, Lithuania, Romania, Slovakia and Slovenia. Regarding the relationship between REC and GDP, we can state the following: (1) there is a short-run bidirectional relationship in Croatia, Czech Republic, Estonia, Poland, Romania and Slovakia; (2) there is short-run unidirectional relationship in Bulgaria and Estonia; (3) there is evidence of a long-run unidirectional relationship in Bulgaria, Croatia, Czech Republic, Latvia, Romania and Slovakia, and we find a long-run bidirectional relationship between REC and GDP in Poland. In Hungary, we didn't find any causal relationship between GDP and ARIV, respectively between GDP and REC. 


\section{Conclusions}

This study examines the impact of economic growth on international tourism demand, measured by two proxies, i.e. the number of international tourist arrivals and the international tourism receipts, over the period 1995-2015 in the Central and Eastern European countries, using the Autoregressive Distributed Lag (ARDL) model. The use of the ARDL model, which is adequate for small sample sizes, the bounds of F-statistics for the cointegration test hints at a long-run relationship between the number of international tourist arrivals (ARIV) and GDP per capita for Bulgaria, Croatia, Czech Republic, Estonia, Lithuania, Slovenia, Romania and Slovakia. Between the international tourism receipts (REC) and GDP per capita we find a long-run relationship for Bulgaria, Croatia, Slovakia, Latvia, Estonia, Poland, Romania and Czech Republic.

Our econometric results indicate that the causality directions between GDP and ARIV, respectively GDP and REC is different in the investigated countries. Thus, only in Croatia and Romania we find a short-term bidirectional relationship both between GDP and ARIV and GDP and REC. Also, a short-term bidirectional relationship was found in Bulgaria and Slovenia but only between GDP and ARIV, while in the Czech Republic, Estonia, Poland and Slovakia we found a short-term bidirectional relationship only between GDP and REC. Regarding the long-term bidirectional relationship, we found one only in Poland's case, having as variables GDP and REC, while in Hungary, an economy with a relatively low contribution of tourism to GDP, no causal relationship was reported.

Further studies are necessary to explore in greater depth the causes of the directions of the observed relationship for the investigated countries, and the differences in short-run versus long-run. Moreover, the derived conclusions are limited by the relatively small available data series and consequently the limited econometric methods which can be used in this case. However, the hypothesis of a bidirectional relationship between economic growth and international tourist arrivals is validated in the short run, while in the long run there is evidence of the TLEG hypothesis. When approaching the relation between economic growth and the international tourism receipts, the hypothesis of a bidirectional relationship is validated for many countries in the short run, while only TLEG is validated on the long run for a consistent number of countries.

Both the examined literature and our own findings confirm that, in specific periods of time, tourism could stimulate economic growth, but later on, the development of the economy can support the expansion of tourism. Moreover, in certain periods / countries / social or political circumstances, the relationship may be bilateral, and in others we may not find any relation. This should not discourage economic research on this topic, but rather make them more applied, i.e. to suggest the most inspired and flexible policies that decision-makers can use to foster economic development by encouraging the tourism sector, and, in specific, the adjustment of the private initiative to the needs for a sustainable economy (Haţegan et al., 2018), but also vice-versa. Thus, the potential of tourism will generate the most appropriate returns, and the periods of economic or political uncertainty will affect the sector to a small extent. Actually, the complex nature of the relation between economic growth and tourism development is confirmed, and the synergies generated by the interdependencies and connections theoretically support the policies to foster tourism development, an industry which still cannot be developed unless a certain level of economic development, infrastructure, services etc is attained. Thus, public policies should focus on political and market stability, promote top industries and well planned investment 
to foster economic development, that will, in turn, provide not only the resources needed for a greater development of tourism, but also generate positive effects related to the attractiveness of the country as destination for international tourists. For fostering international tourism arrivals in countries like Romania and Bulgaria, an increase of revenues per capita is necessary.

\section{References}

Andriotis, K., 2002. Scale of Hospitality Firms and Local Economic Development. The Case of Crete. Tourism Management, 23(4), pp. 333-341.

Antonakakis, N., Dragouni, M. and Filis, G., 2015. How Strong is the Linkage between Tourism and Economic Growth in Europe? Economic Modelling, 44, pp. 142-155.

Apergis, N. and Payne, J., 2012. Research note: Tourism and growth in the Caribbeanevidence from a panel error correction model. Tourism Economics, 18(2), pp. 449-456.

Arslanturk, Y. and Atan, S., 2012. Dynamic relation between economic growth, foreign exchange and tourism incomes: an econometric perspective on Turkey. Journal of Business Economics \& Finance, 1(1), pp. 30-37.

Arslanturk, Y., Balcilar, M. and Ozdemir, Z., 2011. Time-varying linkages between tourism receipts and economic growth in a small open economy. Economic Modeling, 28(2), pp. 664-671.

Aslan, A., 2013. Tourism development and economic growth in the Mediterranean countries: evidence from panel Granger causality tests. Current Issues in Tourism, 17(4), pp. 1-10.

Bac, D.P. and Aksoz, E.O., 2017. Contemporary Challenges for Sustainable Tourism - A Regional Perspective. Oradea Journal of Business and Economics, 2(2), pp. 37-44.

Balaguer, J. and Cantavella-Jorda, M., 2002. Tourism as a long-run economic growth factor: the Spanish case. Applied Economics, 34(7), pp. 877-884.

Bădulescu, D., Bungau, C. and Bădulescu, A., 2015. Sustainable Development Through Sustainable Businesses. An Empirical Research Among Master Students. Journal of Environmental Protection and Ecology, 16(3), pp. 1101-1108.

Brătianu, C. and Vasilache, S., 2010. A factorial analysis of the managerial linear thinking model. Int. J. Innovation and Learning, 8(4), pp. 393-407.

Brida, J., Cortes-Jimenez, I. and Pulina, M., 2014. Has the tourism-led growth hypothesis been violated? A literature review. Current Issues in Tourism, 1(1), pp. 1-37.

Brida, J. and Pulina, M., 2010. A literature review on the tourism-led-growth hypothesis. Working Paper CRENoS 2010/17. Sardinia: Centre for North South Economic Research, University of Cagliari and University of Sassari.

Cárdenas-García, P., Sánchez-Rivero, M.M. and Pulido-Fernández, J., 2015. Does Tourism Growth Influence Economic Development? Journal of Travel Research, 54(2), pp. 206- 221.

Charbel, B., Hamadeh, M. and Samara, N., 2015. The tourism led growth hypothesis: the Lebanese case. Tourism Review, 70(1), pp. 43-55.

Chou, M., 2013. Does tourism development promote economic growth in transition countries? A panel data analysis. Economic Modelling, 33, pp. 226-232. 
Cortés-Jimenez, I. and Pulina, M., 2006. Inbound tourism and Long-run Economic Growth. Current Issues in Tourism, 13(1), pp. 61-74.

Dickey, D. and Fuller, W., 1979. Distribution of the Estimators for Autoregressive Time Series with a unit root. Journal of the American Statistical Association, 74(366), pp. 427-431.

Durbarry, R., 2004. Tourism and economic growth: The case of Mauritius. Tourism Economics, 10(4), pp. 389-401.

Engle, R. and Granger, C., 1987. Co-integration and error correction: representation, estimation and testing. Econometrica, 55(2), pp. 251-276.

Granger, C., 1981. Some properties of time series data and their use in econometric model specification. Journal of Econometrics, 16(1), pp. 121-130.

Haţegan, C.D. and Ivan-Ungureanu, C., 2014. Frameworks for a sustainable development indicators system, Theoretical and Applied Economics, 3(592), pp. 31-44.

Hațegan, C.D., Sirghi, N., Curea-Pitorac, R.-I., and Hațegan, V.-P., 2018. Doing Well or Doing Good: The Relationship between Corporate Social Responsibility and Profit in Romanian Companies. Sustainability, 10(4), pp. 1041-1042.

Jackman, M., 2012. Revisiting the Tourism-Led Growth Hypothesis for Barbados: A Disaggregated Market Approach. Regional and Sectoral Economic Studies, 12(2), pp. 15-26.

Johansen, S., 1988. Statistical analysis of cointegrating vectors. Journal of Economic Dynamics and Control, 12(2-3), pp. 231-254.

Johansen, S. and Juselius, K., 1990. Maximum likelihood estimation and inference on cointegration -with application to the demand for money. Oxford Bulletin of Economics and Statistics, 52(2), pp. 169-210.

Katircioglu, S., 2009. Revising the Tourism-led-growth Hypothesis for Turkey Using the Bounds Test and Johansen Approach for Cointegration. Tourism Management, 30(1), pp. 17-20.

Kim, H., Chen, M. and Jang, S., 2006. Tourism expansion and economic development: the case of Taiwan. Tourism Management, 27(5), pp. 925-933.

Lanza, A. and Pigliaru, F., 2000. Why are tourism countries small and fast-growing? In: A. Fossati and G. Panella, eds. Tourism and Sustainable Economic Development. Dordrecht: Kluwer Academic Publishers. pp. 57-69.

Lee, C.-C. and Chang, C.-P., 2008. Tourism development and economic growth: A closer look at panels. Tourism Management, 29(1), pp. 180-192.

Oh, C.-O., 2005. The contribution of tourism development to economic growth in the Korean economy. Tourism Management, 26(1), pp. 39-44.

Ozturk, I. and Acaravci, A., 2009. On the causality between tourism growth and economic growth: Empirical evidence from Turkey. Transylvanian Review of Administrative Sciences, 25(5), pp. 73-81.

Payne, J. and Mervar, A., 2010. Research Note: The Tourism-Growth Nexus in Croatia. Tourism Economics, 16(4), pp. 1089-1094.

Pesaran, M. and Shin, Y., 1999. An Autoregressive Distributed Lag Modelling Approach to Cointegration Analysis. Chapter 11. In: S. Strom, ed. Econometrics and Economic 
Theory in 20 th Century: The Ragnar Frisch Centennial Symposium. Cambridge: Cambridge University Press. pp. 371-413.

Pesaran, M., Shin, Y. and Smith, R., 2001. Bounds testing approaches to the analysis of level relationships. Journal of Applied Econometrics, 16(3), pp. 289-326.

Popescu, D., Săseanu, A., Bulin, D. and Calabro, G., 2014. Econometric Models in Romanian Tourism under the Impact of Sustainable Development. Amfiteatru Economic, 16 (Special Issue No. 8), pp. 1063-1075.

Ridderstaat, J., Croes, R. and Nijkamp, P., 2016. The Tourism Development-Quality of Life Nexus in a Small Island Destination. Journal of Travel Research, 55(1), pp. 79-94.

Rivera, M., 2016. The synergies between human development, economic growth, and tourism within a developing country: An empirical model for Ecuador. Journal of Destination Marketing and Management, 6(3), pp. 221-232.

Tang, C. and Jang, S., 2009. The tourism-economy causality in the United States: A subindustry level examination. Tourism Management, 30(4), pp. 553-558.

Tang, C. and Tan, E., 2015. Does tourism effectively stimulate Malaysia's economic growth? Tourism Management, 46(3), pp. 158-163.

Ţigu, G., 2012. New Challenges for Tourism Destination Management in Romania. In: M. Kasimoglu and K. Avdin, eds. Strategies for Tourism Industry - Micro and Macro Perspectives. London: InTechOpen. pp. 167-184.

World Bank, 2017. World Development Indicators. [online] Available at: <http://databank. worldbank.org/data/reports.aspx?Code=NY.GDP.MK-TP.CD\&id=1ff4a498\&report_ name $=$ Popular-Indicators\&populartype $=$ series\&ispo-pular $=y>$ [Accessed 3 June 2017].

World Tourism Organization (UNWTO), 2016. Tourism highlights. Madrid: UNWTO. 
Appendix no. 1: Estimated coefficients from ARDL models (ARIV and GDP)

\begin{tabular}{|c|c|c|c|c|}
\hline Regressors & Bulgaria & Croatia & $\begin{array}{c}\text { Czech } \\
\text { Republic }\end{array}$ & Estonia \\
\hline \multicolumn{5}{|c|}{ Long-run elasticities } \\
\hline GDP & $1.4295(0.00)$ & $1.6884(0.00)$ & $0.9569(0.00)$ & $1.5470(0.00)$ \\
\hline Intercept & $1.3106(0.00)$ & & $2.7435(0.01)$ & \\
\hline ECT(-1) & $-0.7358(0.00)$ & $-0.3961(0.00)$ & $-0.5462(0.00)$ & $-0.1973(0.05)$ \\
\hline \multicolumn{5}{|c|}{ Short-run elasticities } \\
\hline ARIV(-1) & $0.2641(0.10)$ & $0.6038(0.00)$ & $0.4537(0.01)$ & $0.8026(0.00)$ \\
\hline GDP & $1.0519(0.00)$ & $1.7581(0.02)$ & $0.5227(0.03)$ & $0.3053(0.04)$ \\
\hline GDP(-1) & & $-1.089(0.1)$ & & \\
\hline Intercept & $0.9644(0.00)$ & & $1.4987(0.02)$ & \\
\hline ARDL model & $(1,0)$ & $(1,1)$ & $(1,0)$ & $(1,0)$ \\
\hline R-squared & 0.97 & 0.93 & 0.81 & 0.97 \\
\hline Independent & $1.5338(0.26)$ & $2.0858(0.16)$ & $1.4515(0.24)$ & $1.1434(0.29)$ \\
\hline Homoscedasticity & $0.6132(0.55)$ & $0.8536(0.48)$ & $1.4116(0.27)$ & $1.8501(0.18)$ \\
\hline Normality & $0.6535(0.72)$ & $0.8481(0.65)$ & $1.6253(0.44)$ & $0.0796(0.96)$ \\
\hline Regressors & Lithuania & Romania & Slovakia & Slovenia \\
\hline \multicolumn{5}{|c|}{ Long-run elasticities } \\
\hline GDP & $0.5473(0.01)$ & $0.1064(0.04)$ & $0.4559(0.06)$ & $1.4851(0.00)$ \\
\hline Intercept & $3.9844(0.00)$ & $-0.0013(0.23)$ & $4.2420(0.00)$ & \\
\hline ECT(-1) & $-0.5587(0.00)$ & $-0.7698(0.00)$ & $-0.4049(0.01)$ & $-0.1077(0.21)$ \\
\hline \multicolumn{5}{|c|}{ Short-run elasticities } \\
\hline ARIV(-1) & $0.4412(0.02)$ & $0.2301(0.26)$ & $0.5950(0.00)$ & $0.8922(0.00)$ \\
\hline GDP & $1.1271(0.07)$ & $0.0819(0.02)$ & $1.8523(0.00)$ & $0.1599(0.1)$ \\
\hline GDP(-1) & $-0.821(0.1)$ & & $0.9494(0.09)$ & \\
\hline Intercept & $2.2262(0.00)$ & $-0.001(0.1)$ & $1.7176(0.00)$ & \\
\hline ARDL model & $(1,1)$ & $(1,0)$ & $(1,1)$ & $(1,0)$ \\
\hline R-squared & 0.77 & 0.34 & 0.90 & 0.96 \\
\hline Independent & $0.033(0.85)$ & $0.039(0.84)$ & $2.7921(0.11)$ & $0.0373(0.84)$ \\
\hline Homoscedasticity & $2.1246(0.13)$ & $0.8813(0.43)$ & $1.2847(0.33)$ & $0.8547(0.44)$ \\
\hline Normality & $6.3886(0.04)$ & $0.4963(0.78)$ & $0.6350(0.72)$ & $3.8343(0.14)$ \\
\hline
\end{tabular}

Notes: p-value are in ().

Source: authors' estimates using Eviews 9 
Appendix no. 2: Estimated coefficients from ARDL models (Receipts and GDP)

\begin{tabular}{|c|c|c|c|c|}
\hline Regressors & Bulgaria & Croatia & Slovakia & Latvia \\
\hline \multicolumn{5}{|c|}{ Long-run elasticities } \\
\hline GDP & $2.4915(0.00)$ & $3.7982(0.00)$ & $2.9573(0.00)$ & $2.1687(0.00)$ \\
\hline Intercept & & $-5.754(0.00)$ & $-3.1494(0.00)$ & \\
\hline ECT(-1) & $-0.7611(0.00)$ & $-0.7957(0.00)$ & $-0.6200(0.00)$ & $-0.4754(0.00)$ \\
\hline \multicolumn{5}{|c|}{ Short-run elasticities } \\
\hline REC(-1) & $0.7350(0.00)$ & $0.2042(0.09)$ & $0.7712(0.00)$ & $0.6433(0.00)$ \\
\hline REC(-2) & $-0.4962(0.03)$ & & $-0.3912(0.03)$ & $-0.1188(0.1)$ \\
\hline GDP & $3.9329(0.00)$ & $3.0223(0.00)$ & $3.0014(0.00)$ & $1.0311(0.00)$ \\
\hline GDP(-1) & $-2.0366(0.06)$ & & $-1.1678(0.22)$ & \\
\hline Intercept & & $-4.5785(0.00)$ & $-1.9526(0.01)$ & \\
\hline ARDL model & $(2,1)$ & $(1,0)$ & $(2,1)$ & $(2,0)$ \\
\hline R-squared & 0.94 & 0.98 & 0.98 & 0.95 \\
\hline Independent & $1.9219(0.18)$ & $0.1741(0.68)$ & $1.4415(0.27)$ & $0.2002(0.66)$ \\
\hline Homoscedasticity & $2.1096(0.13)$ & $1.0034(0.38)$ & $1.1143(0.31)$ & $0.1881(0.90)$ \\
\hline Normality & $1.2636(0.53)$ & $2.6543(0.26)$ & $0.1240(0.93)$ & $1.7786(0.41)$ \\
\hline Regressors & Estonia & Poland & Romania & $\begin{array}{c}\text { Czech } \\
\text { Republic }\end{array}$ \\
\hline \multicolumn{5}{|c|}{ Long-run elasticities } \\
\hline GDP & $1.4848(0.00)$ & $8.0328(0.00)$ & $2.9793(0.00)$ & $2.3011(0.00)$ \\
\hline Intercept & $2.9245(0.00)$ & & $-2.3985(0.08)$ & \\
\hline ECT(-1) & $-0.6262(0.00)$ & $-0.5457(0.00)$ & $-0.5827(0.00)$ & $-0.4623(0.00)$ \\
\hline \multicolumn{5}{|c|}{ Short-run elasticities } \\
\hline REC(-1) & $0.3737(0.05)$ & $0.8139(0.00)$ & $0.4172(0.01)$ & $0.5376(0.00)$ \\
\hline GDP & $0.9298(0.00)$ & $7.1729(0.00)$ & $1.7362(0.00)$ & $1.0638(0.00)$ \\
\hline GDP(-1) & & $-6.740(0.00)$ & $-1.8528(0.08)$ & \\
\hline Intercept & $1.8314(0.01)$ & & & \\
\hline ARDL model & $(1,0)$ & $(1,1)$ & $(1,0)$ & $(1,0)$ \\
\hline R-squared & 0.90 & 0.86 & 0.93 & 0.92 \\
\hline Independent & $1.7067(0.20)$ & $0.2520(0.62)$ & $0.8129(0.38)$ & $1.7923(0.19)$ \\
\hline Homoscedasticity & $1.0163(0.38)$ & $0.3699(0.77)$ & $0.1694(0.84)$ & $1.2335(0.31)$ \\
\hline Normality & $1.5787(0.45)$ & $0.594(0.74)$ & $1.0847(0.58)$ & $0.094(0.95)$ \\
\hline
\end{tabular}

Notes: p-value are in (). 